\title{
Faraq Perkahwinan bagi Pasangan Tak Sah Taraf di Negeri Sembilan
}

\author{
Judicial Separation of Illegal Marriage In Negeri Sembilan \\ WAN ABDUL FATTAH WAN ISMAIL*, HASNIZAM HASHIM, \\ SYAHIRAH ABDUL SHUKOR \& ASMA HARUN ${ }^{1}$
}

\begin{abstract}
Islam stressed on the importance of a valid marriage. If a marriage does not comply its requirement and conditions according to Shariah, it will raise negative implications not only on the status of the marriage, but also it will effect the status of the child. Hence, the marriage must be separated. Generally, the Muslim scholars define faraq as separation or dissolution of marriage through talaq or otherwise. However, according to Islamic law in Malaysia, faraq is not a dissolution of marriage via talaq, but it is an annulment of marriage due to non-fulfillment of terms and conditions which laid down by Shariah. In context of abiding the conditions and terms to marriage, having a wali is one of the conditions in solemnization of a valid marriage. Marriage which is solemnized by a non-qualified wali such as in cases of illegitimate children will cause the marriage to be separated. Data in this article is obtained from the reported cases tried in the Shariah Courts in Negeri Sembilan. Interviews were conducted with those legal practitioners such as syaria lawyers, religious officers, and judges from Shariah Courts in Negeri Sembilan who deal directly with faraq cases.
\end{abstract}

Keywords: faraq, illegitimate child, illegal marriage, judicial separation, shariah law

Perkahwinan adalah suatu tuntutan agama dalam meraikan fitrah semula jadi penciptaan manusia. Bertujuan untuk menjaga keturunan, memelihara kesucian diri, melaksanakan tuntutan syariat, memperoleh ketenangan hidup, kasih sayang dan ketenteraman sepertimana yang dinyatakan oleh Allah SWT di dalam Surah al-Rum ayat 21. Bagi memastikan ikatan suci ini mencapai matlamat tersebut, ia hendaklah dibina atas rukun-rukun dan syarat-syarat yang telah ditetapkan syarak. Rukun bertujuan -rukun yang dimaksudkan di sini ialah pasangan lelaki dan perempuan, dua saksi yang adil, sighah dan wali. Seseorang wali hendaklah memenuhi kriteria-kriteria yang telah ditetapkan syarak, bertujuan memenuhi ketetapan syariat Islam. Kegagalan mematuhi ketetapan syarak tersebut boleh menyebabkan, perkahwinan tersebut perlu difaraq atau dinamakan juga sebagai 'pemisahan kehakiman' seperti dalam kes mewalikan anak tak sah taraf dengannya.

\footnotetext{
1 Wan Abdul Fattah Wan Ismail*(Corresponding author), Ph.D., Associate Professor, Faculty of Syariah \& Law, Islamic Science of Malaysia, Bandar Baru Nilai, 71800 Nilai, Negeri Sembilan, email: wanfattah@usim.edu.my; Hasnizam Hashim, Ph.D., Senior Lecturer, Faculty of Syariah \& Law, Islamic Science of Malaysia, Bandar Baru Nilai, 71800 Nilai, Negeri Sembilan, email: hasnizam@usim.edu.my; Syahirah Abdul Shukor. Ph.D., Senior Lecturer, Faculty of Syariah \& Law, Islamic Science of Malaysia, Bandar Baru Nilai, 71800 Nilai, Negeri Sembilan, email: syahirah@usim.edu.my; Asma Harun, Officer at Majlis Agama Islam Negeri Sembilan Beg Berkunci No. 22, 70990 Seremban, Negeri Sembilan. email: asma061105@gmail.com.
} 
Menurut Sophia Ahmad (2013), statistik kelahiran anak luar nikah atau anak tak sah taraf di Malaysia seperti yang telah direkodkan oleh Jabatan Pendaftaran Negara (JPN) pada tahun 2013 adalah berjumlah seramai 159,725 orang. Dengan jumlah seramai ini, tidak mustahil penyumbang kepada bilangan statistik ini turut berpunca daripada perkahwinan yang tidak sah akibat daripada wali yang tidak diiktiraf oleh syarak. Di dalam kertas kerja ini, penulis akan membincangkan tentang konsep faraq dan aspek-aspek perundangan berkaitan faraq perkahwinan bagi pasangan tidak sah taraf. Perbincangan juga akan turut mengupas punca berlakunya kes perwalian anak tak sah taraf, implikasinya dan penguatkuasaan peruntukan sedia ada khususnya di Negeri Sembilan dalam menangani permasalahan ini. Maklumat yang dibincangkan di dalam kertas kerja ini adalah hasil temu bual bersama mereka yang terlibat secara langsung mengendalikan kes-kes faraq perkahwinan di Negeri Sembilan.

\section{Faraq Perkahwinan Kerana Isu Perwalian}

Faraq dari segi bahasa, berasal daripada perkataan 'faraqa' dan kata terbitannya ialah 'tafriq' yang bermaksud pemisahan atau pembubaran (Ibrahim Mustafa \& Muhammad 1989). Perkataan faraq dalam al-Quran juga membawa maksud cerai atau pisah (Ali al-Khafif: 13). Firman Allah SWT dalam Surah An-Nisa' ayat 130 yang bermaksud: 'Dan jika kedua-dua bercerai, maka Allah akan cukupkan keperluan masing-masing dari limpah kurnia-Nya. Limpah kurniaan Allah itu Maha luas dan Maha bijaksana'.

Dari segi istilah, definisi faraq yang digunakan di dalam kitab-kitab fiqh tidak banyak bezanya dengan definisi faraq dari segi bahasa. Faraq dari segi istilah bermaksud pemisahan atau pembubaran bagi perkahwinan sama ada melalui talak atau selainnya. Abdul Karim Zaydan (2012) berpendapat, faraq ialah pemutusan ikatan perkahwinan dia antara pasangan suami isteri atas sebab-sebab tertentu sama ada melalui talak dan fasakh. Namun begitu, dalam sistem perundangan Islam di Malaysia, istilah faraq lebih merujuk kepada pembubaran perkahwinan bukan melalui talak (Jabatan Kemajuan Islam Malaysia 2017).

Terdapat beberapa sebab yang membolehkan Mahkamah melakukan faraq atau pemisahan kehakiman terhadap sesebuah 'perkahwinan'. Di antara sebab berlakunya faraq ialah perkahwinan dengan sesama mahram, perkahwinan dengan perempuan yang sedang menjadi isteri kepada orang lain, perkahwinan dengan orang bukan Islam, perkahwinan dengan lima orang perempuan dalam satu masa/ akad, perkahwinan seorang perempuan dengan berwalikan 'wali' yang tidak diiktiraf perwaliannya oleh Syarak dan lain-lain sebab yang digariskan oleh syarak. Perkara ini telah dinyatakan secara umum dalam seksyen 7(1) dan seksyen 11, Enakmen Undang-Undang Keluarga Islam (Negeri Sembilan) 2003. Penulisan ini walau bagaimanapun hanya akan membincangkan satu sahaja aspek sahaja iaitu faraq perkahwinan seorang perempuan dengan berwalikan 'wali' yang tidak diiktiraf perwaliannya oleh syarak atau perwalian anak yang tidak sah taraf.

\section{Faraq Perkahwinan dalam Kes Perwalian Perkahwinan Anak Tak Sah Taraf}

Wali dari segi bahasa bermaksud kasih sayang dan pertolongan. Dari segi istilah, wali adalah merupakan pihak yang mempunyai hak atau autoriti untuk membuat keputusan dan mengawal selia urusan orang lain (Mustafa al-Khin \& Mustafa al-Bugha 1996). Dalam konteks perkahwinan, Wali merujuk kepada individu yang mempunyai kuasa untuk melakukan akad perkahwinan terhadap orang yang di bawah jagaannya tanpa bergantung kepada keizinan. Wali dalam konteks ini perlulah memenuhi syarat-syarat yang telah ditetapkan syarak (Al-Zuhailiy 2007). 
Wali merupakan salah satu rukun nikah dan tanpanya pernikahan adalah tidak sah. Pendapat ini telah disepakati oleh jumhur ulamak berdasarkan banyak dalil. Antaranya ialah sabda Rasulullah SAW yang bermaksud: 'Mana-mana wanita yang bernikah tanpa izin walinya, maka nikahnya batal, maka nikahnya batal, maka nikahnya batal, jika ia menggaulinya maka ia berhak mendapat maharya sebagai ganti terhadap apa yang dihalalkan dari kemaluannya, sekiranya mereka bertengkar maka sultan sebagai wali kepada mereka yang tidak mempunyai wali' (Al-Tirmizi 1975).

Dalam Seksyen 7(1) Enakmen Undang-Undang Keluarga Islam (Negeri Sembilan) 2003, kedudukan wali dalam perkahwinan sangat penting bagi memastikan sesuatu perkahwinan itu sah menurut hukum syarak. Menurut seksyen 7 (1), sesuatu akad nikah dianggap sah dari segi hukum syarak dan peruntukan Enakmen Undang-Undang Keluarga Islam (Negeri Sembilan) 2003 ia dilaksanakan oleh wali yang layak menurut syarak dan akad tersebut dilaksanakan di hadapan Ketua Pendaftar atau Pendaftar. Di dalam peruntukan yang sama, sekiranya akad nikah melalui wakil wali, maka ia hendaklah dilaksanakan di hadapan dan dengan kebenaran Ketua Pendaftar atau Pendaftar ataupun Ketua Pendaftar atau Pendaftar itu sendiri menjadi wakil wali.

\section{Susunan Wali}

Terdapat tiga kategori Wali iaitu Wali Hakim, Wali Mujbir dan juga Wali Ikhtiar. Wali Hakim atau Wali Raja adalah bagi pihak yang tidak mempunyai wali atau tidak memiliki wali sah menurut hukum syarak seperti wali enggan, wali tinggal terlalu jauh, wali akrab yang tidak dapat dikesan dan termasuklah juga bagi kes anak tak sah taraf. Manakala Wali Mujbir dan Wali Ikhtiar pula merupakan wali nasab kepada wanita yang diwalikan olehnya (al-Syirazi 1996). Seksyen 7(2) Enakmen Undang-Undang Keluarga Islam (Negeri Sembilan) 2003 menyatakan:

Jika sesuatu perkahwinan itu melibatkan seorang perempuan yang tidak mempunyai wali daripada nasab, mengikut Hukum Syarak, perkahwinan itu hendaklah diakadnikahkan hanya oleh wali Raja.

Dalam tafsiran Seksyen 2 menyatakan 'Wali Raja' ialah wali yang ditauliahkan oleh Yang diPertuan Agong dalam hal Wilayah Persekutuan, Melaka, Pulau Pinang, Sabah dan Sarawak, atau oleh Raja, dalam hal mana-mana Negeri lain, untuk mengahwinkan perempuan yang tidak mempunyai wali nasab. Dalam seksyen yang sama, 'nasab' pula merujuk kepada keturunan yang berasaskan pertalian darah yang sah. Seksyen 2 dan 7(2) secara jelas menyebut perkataan wali dan hubungan dengan nasab. Keadaan ini menunjukkan bahawa sesuatu perkahwinan itu hanya diiktiraf menurut perundangan sekiranya wali dan wanita yang diwalikan mempunyai pertalian nasab yang sah menurut syarak. Jika perkahwinan itu berlaku tanpa wali yang diiktiraf syarak, maka mahkamah boleh membuat 'pemisahan kehakiman' atau faraq terhadap perkahwinan tersebut.

\section{Kaedah Sabitan Nasab}

Berikut adalah merupakan kaedah atau sebab sabitan nasab kepada seseorang:

\section{Perkahwinan Sahih}


Perkahwinan yang sahih merujuk kepada pernikahan yang benar-benar berlaku menurut hukum syarak seperti menepati segala rukun dan syarat perkahwinan, berlaku persetubuhan, anak yang dilahirkan dalam tempoh tertentu dari akad perkahwinan dan pernah berada bersama-sama walaupun dalam tempoh yang singkat. Rasulullah SAW bersabda yang bermaksud: 'Anak itu bagi pasangan (tempat tidur) dan bagi penzina itu adalah hukuman rejam' (al-Bukhari 1422).

Berkenaan dengan tempoh masa, jumhur ulamak bersepakat bahawa tempoh paling singkat seseorang anak itu boleh dinasabkan kepada bapanya adalah 6 bulan selepas tarikh akad. (Uqlah, 1989). Seksyen 111, Enakmen Undang-Undang Keluarga Islam (Negeri Sembilan) 2003 menetapkan bahawa seseorang anak itu hanya boleh dinasabkan kepada bapanya apabila jika dia dilahirkan oleh perempuan yang dikahwininya lebih daripada enam bulan qamariah dari tarikh perkahwinannya itu atau dalam masa empat tahun qamariah selepas perkahwinannya itu dibubarkan sama ada pembubaran itu berlaku disebab kematian lelaki itu atau oleh sebab perceraian, dan perempuan itu pula tidak berkahwin semula. Jika lelaki itu menafikan anak yang dilahirkan isterinya itu adalahnya, maka penafian itu boleh dibuat dengan cara li'an di hadapan Mahkamah. Dalam Seksyen 112, Enakmen yang sama menyatakan: Jika anak itu dilahirkan lebih daripada empat tahun qamariah selepas perkahwinan itu dibubarkan sama ada oleh sebab kematian lelaki itu atau oleh sebab perceraian, lelaki itu tidak boleh disifatkan sebagai bapa anak itu melainkan jika lelaki itu atau mana-mana warisnya menegaskan bahawa anak itu ialah anak lelaki itu.

Dalam kes pengakuan yang dibuat oleh seorang lelaki bahawa anak itu adalah anaknya, maka perundangan telah menggariskan beberapa syarat perlu dipenuhi oleh pihak yang membuat pengakuan itu. Seksyen 115 memperuntukkan:

Jika seseorang lelaki mengaku seorang lain, sama ada secara nyata atau secara tersirat, sebagai anaknya yang sah, lelaki itu hendaklah disifatkan sebagai bapa anak itu jika, syarat-syarat yang berikut dipenuhi, iaitu-

(a) tiada seseorang lain disifatkan sebagai bapa anak itu;

(b) perbezaan antara umur lelaki itu dengan umur anak itu memunasabahkan pertalian antara mereka sebagai bapa dan anak;

(c) jika anak itu telah akil baligh, dan dia boleh membuat keputusan, anak itu telah bersetuju dia diakui sebagai anak;

(d) lelaki dan ibu anak itu mungkin boleh disatukan dengan sah dalam perkahwinan pada masa pembenihan;

(e) pengakuan itu bukannya sekadar pengakuan bahawa anak itu ialah anaknya, bahkan juga bahawa anak itu ialah anak sah tarafnya;

(f) lelaki itu berkeupayaan membuat kontrak;

(g) pengakuan itu dibuat dengan tujuan semata-mata untuk memberi taraf kesahtarafan; atau

(h) pengakuan itu adalah jelas maksudnya dan anak itu diakui sebagai anak kandungnya.

Apabila seseorang itu telah membuat pengakuan bahawa anak itu adalah anaknya dan lelaki tersebut juga telah memenuhi syarat sepertimana yang telah diperuntukkan dalam Seksyen 115. Perkara ini pula disahkan oleh mahkamah, maka pengakuan tersebut tidak boleh ditarik balik sewenang-wenangnya. Seksyen 120 menyatakan: 
Apabila pengakuan atau pengesahan dibuat tentang pertalian sebagai bapa dan anak atau tentang perkeluargaan atau persaudaraan, maka pengakuan atau pengesahan itu tidak boleh dibatalkan.

\section{Perkahwinan Fasid}

Perkahwinan yang fasid berlaku apabila salah satu syarat-syarat sah nikah tidak dipenuhi seperti perkahwinan tanpa saksi. Perkahwinan seumpama ini wajib difaraqkan. Sekiranya pasangan tersebut mempunyai anak, jumhur ulamak berpendapat bahawa anak tersebut boleh dinasabkan kepada bapanya dengan syarat persetubuhan hakiki dan bayi yang dilahirkan itu mestilah 6 bulan atau lebih selepas berlakunya persetubuhan.

Dalam kes Norasiah bt Abd. Rahman dan Mohd Nasir b Mohd Rosly merupakan anak tidak sah taraf dengan bapanya. Apabila Norasiah berkahwin pada 28 Oktober 2006, dia telah menjadikan abangnya sebagai wali yang sepatutnya berwalikan dengan wali hakim. Apabila kes tersebut dilaporkan ke Mahkamah Syariah dan Mahkamah berpuas hati dengan keterangan yang telah diberikan, maka perkahwinan Norasiah bt Abd. Rahman dan Mohd Nasir b Mohd Rosly telah difaraqkan pada 10 Januari 2012 setelah hampir 4 tahun mereka mendirikan rumah tangga.

\section{Persetubuhan Syubhah}

Dalam kes persetubuhan tersilap dan persetubuhan yang berlaku di dalam perkahwinan yang disangka sah sedangkan perkahwinannya itu sebenarnya tidak sah dari segi hukum syarak, hukuman hudud tidak boleh dilaksanakan kerana persetubuhan yang berlaku adalah termasuk dalam kategori persetubuhan syubhah (wati syubhah). Pun begitu, pasangan tersebut wajib difaraqkan. Jika perkahwinan yang difaraqkan disebabkan persetubuhan syubhah, maka anak tersebut dinasabkan kepada bapanya. Enakmen Undang-Undang Keluarga Islam (Negeri Sembilan) 2003 memberi penjelasan mengenai 'persetubuhan syubhah' seperti berikut:

Seksyen 2: Persetubuhan yang dilakukan atas anggapan sah akad nikah akan tetapi sebenarnya akad itu tidak sah (fasid) atau persetubuhan yang berlaku secara tersilap dan termasuk mana-mana persetubuhan yang tidak dihukum Had dalam Islam .

Seksyen 114: Jika seorang lelaki melakukan persetubuhan syubhah dengan seorang perempuan, dan kemudiannya perempuan itu melahirkan seorang anak dalam tempoh antara enam bulan qamariah hingga empat tahun qamariah selepas persetubuhan itu, maka lelaki itu hendaklah disifatkan sebagai bapa anak itu.

\section{Implikasi Perwalian Anak Tak Sah Taraf, Peruntukan Undang-Undang dan Contoh Kes Yang Berlaku di Negeri Sembilan}

Anak yang lahir bukan daripada perkahwinan yang sahih, fasid atau syubhah adalah dianggap sebagai anak zina atau anak tidak sah taraf dan tidak boleh dinasabkan kepada bapanya. Jika perkahwinan itu diwalikan oleh wali yang tak sah taraf tanpa pengetahuan anak tersebut, perkahwinan itu wajib difaraqkan. Pernikahan semula boleh dilakukan dengan menggunakan wali hakim seperti yang diperuntukkan dalam seksyen 7(2) Enakmen Undang-Undang Keluarga Islam (Negeri Sembilan) 2003: 
Jika sesuatu perkahwinan itu melibatkan seorang perempuan yang tidak mempunyai wali daripada nasab, mengikut Hukum Syarak, perkahwinan itu hendaklah diakadnikahkan hanya oleh wali Raja.

Seksyen 7(2) di atas jelas memperuntukkan bahawa orang yang layak untuk menjadi wali selain wali Hakim atau Wali Raja ialah wali yang mempunyai hubungan nasab keturunan yang sah dengan wanita yang diwalikan. Seksyen 2 menyatakan "nasab" ertinya: "keturunan yang berasaskan pertalian darah yang sah". Berdasarkan peruntukan ini, hubungan nasab secara sah menurut hukum syarak merupakan elemen penting bagi memastikan sesuatu perkahwinan tersebut sah ataupun sebaliknya. Mahkamah mempunyai kuasa untuk memfaraqkan perkahwinan yang berwalikan dengan wali yang tidak layak.

Secara keseluruhannya kes-kes faraq perkahwinan yang berlaku di seluruh Negeri Sembilan antara tahun 2006 hingga tahun 2016 berdasarkan kepada data maklumat faraq pernikahan Negeri Sembilan 2006-2016 adalah sebanyak 40 kes. Kes faraq perkahwinan yang paling banyak adalah melibatkan langkau wali. Namun dalam tempoh yang sama, bagi kes faraq disebabkan pasangan tak sah taraf di Negeri Sembilan ialah sebanyak 6 kes. Walaupun kes faraq pasangan tak sah taraf adalah lebih sedikit atau 15\% dari kes faraq keseluruhannya, namun ia tidak boleh dipandang ringan. Tidak mustahil bilangan ini akan meningkat jika ia tidak dibendung dan diberi kesedaran secara lebih serius kepada masyarakat.

Dalam kes Rohayu bt Idris dan Abd Karim bin Hamzah (bukan nama sebenar) telah berkahwin pada 1 Jun 2006. Rohayu telah mendakwa ibunya telah mengaku bahawa beliau telah mengandung sebelum akad nikah secara sah dibuat. Tarikh perkahwinan ibunya ialah 27 Jun 1981 dan tarikh lahir Rohayu ialah 22 Januari 1982 iaitu tidak sampai 6 bulan yang merupakan syarat sah seseorang itu boleh dinasabkan kepada bapanya. Setelah itu, bapanya yang tidak sah taraf dengannya telah menjadi walinya semasa mereka berkahwin. Kes tersebut telah dibawa ke Mahkamah Syariah dan Mahkamah telah meluluskan faraq pada 27 Januari 2015 dengan idah 3 kali suci. Begitu juga, dalam kes Zakiah binti Zahrin dan Alim bin Abdul Razak (bukan nama sebenar) pada 1 Julai 2013. Mereka telah diwalikan oleh bapa yang tidak sah taraf dengan Zakiah. Ibu bapa Zakiah telah berkahwin pada 6 Januari 1979 dan Zakiah telah dilahirkan pada 5 Februari 1979. Tempoh kelahiran adalah adalah kurang dari 6 bulan dari akad nikah secara sah. Kes ini di laporkan ke Mahkamah dan diputuskan perkahwinan antara pasangan ini difaraqkan pada 17 Julai 2013 dengan Idah 3 kali suci.

Selain itu Faraq perkahwinan juga dalam kes Norasiah bt Abd. Rahman dan Mohd Nasir b Mohd Rosly (bukan nama sebenar). Dalam kes ini Norasiah juga anak tidak sah taraf dengan bapanya. Apabila Norasiah berkahwin pada 28 Oktober 2006, dia telah berwalikan dengan abangnya, sedangkan walinya ketika itu sepatutnya ialah wali hakim. Apabila kes tersebut dilaporkan ke Mahkamah Syariah dan Mahkamah berpuas hati dengan keterangan yang telah diberikan, maka mahkamah bersetuju untuk memfaraqkan perkahwinan tersebut pada 10 Januari 2012 setelah hampir 4 tahun pasangan tersebut hidup bersama. Dalam kes Nor Safiah binti Zulkifli dan Muhammad Sofi bin Amran (bukan nama sebenar), mereka telah difaraqkan pada 18 Mei 2011. Bapa Safiah telah mewalikan perkahwinannya dengan Muhammad Sofi sedangkan dia tidak sah taraf dengan Safiah. Tarikh perkahwinan bapa Safiah dengan ibunya pada 12 Oktober 1985 dan Safiah dilahirkan pada 30 Januari 1986. Di sini jelas menunjukkan, tempoh kelahiran dengan akad nikah yang sah antara ibu bapa Safiah tidak sampai pun 4 bulan. Keadaan ini menunjukkan bahawa ibu safiah telah pun mengandung semasa akad nikah dijalankan. Maka Safiah merupakan anak tak sah taraf dengan bapanya dan sekali gus tidak berhak untuk menjadi wali. Keadaan yang sama juga 
berlaku kepada pasangan Muhammad Razin bin Hassan dan Nurul Farhana bt Lokman (bukan nama sebenar) dan juga Munirah bt Nordin dan Abd Rahim bin Yusof (bukan nama sebenar), yang mana masing-masing telah difaraqkan kerana berwalikan dengan wali yang tidak sah taraf dengannya.

\section{Faktor Kes Perwalian Anak Tak Sah Taraf di Negeri Sembilan}

Hasil daripada temu bual yang telah dibuat terhadap responden-responden seperti pegawaipegawai syariah dan peguam syarie dan penilaian terhadap kes-kes yang telah dilaporkan, terdapat beberapa faktor berlakunya kes perwalian anak tak sah taraf, di antara faktor-faktor yang dikenal pasti adalah seperti berikut:

1. Kecetekan Pengetahuan Agama: Kejahilan dan kecetekan tentang hukum hakam merupakan faktor utama berlakunya kes perwalian anak tak sah taraf. Pihak yang ingin menjadi wali perlulah memahami syarat-syarat seseorang wali, adakah mereka telah memenuhi syaratsyarat perwalian atau sebaliknya. Pasangan yang ingin melangsungkan perkahwinan juga perlu memahami kepentingan wali nasab dan kesannya terhadap akad nikah yang bakal dilaksanakan menurut hukum syarak. Pihak wali perlu sedar bahawa implikasi perwalian terhadap anak tak sah taraf adalah amat serius dari sudut sabitan nasab selain perkahwinan yang dilaksanakan perlu difaraqkan. Oleh itu, wali dan pasangan yang ingin berkahwin perlu mendalami ilmu hukum hakam berkaitan perkahwinan khususnya perwalian dan anak tak sah taraf. Pihak-pihak yang mengendalikan kursus-kursus perkahwinan juga perlu menilai semula kandungan kursus serta memberikan penerangan berkaitan hukum hakam permasalahan ini.

2. Kurangnya Penekanan dalam Modul Kursus Perkahwinan Berkaitan Anak Tak Sah Taraf: Keperluan untuk melakukan penilaian semula terhadap kandungan modul kursus perkahwinan perlu dilakukan bagi menangani permasalahan semasa yang berlaku. Jabatan Agama Islam Negeri-negeri perlu memandang serius tentang peningkatan jumlah anakanak luar nikah di kalangan umat Islam seperti yang dilaporkan di dalam media Massa. Pihak-pihak yang mengendalikan kursus-kursus perkahwinan juga perlu menilai semula kandungan kursus serta memberikan penerangan berkaitan hukum hakam permasalahan ini. Dalam hal ini, Jabatan Agama Islam Negeri boleh mengadakan perbincangan meja bulat dengan pihak-pihak berkaitan seperti Kementerian Pembangunan Wanita, Keluarga dan Masyarakat (KPWKM), Jabatan Kebajikan Masyarakat dan lain-lain bagi memastikan modul yang dibina untuk kursus-kursus perkahwinan menepati permasalahan semasa khususnya berkaitan permasalahan anak tak sah taraf.

3. Prosedur dan Penguatkuasaan yang Longgar: Bagi mengelakkan kes perwalian terhadap anak tak sah taraf ini berlaku lebih parah, maka prosedur perkahwinan terhadap wali perlu diperketat. Kelayakan seseorang wali perlu disahkan sekurang-kurangnya oleh dua ahli keluarga yang terdekat. Selain itu juga hukuman yang agak berat juga perlu dikenakan bagi pihak-pihak yang memandang enteng berkaitan perwalian terhadap anak tak sah taraf. Peruntukan yang sedia ada seperti dalam Seksyen 39 dan 40 Enakmen Undang-Undang Keluarga Islam (Negeri Sembilan) 2003 agak kurang relevan dengan keadaan semasa. Hukuman lebih berat perlu dikenakan bagi mendidik dan memastikan masyarakat lebih cakna berkaitan kesan perwalian terhadap anak tak sah taraf. 


\section{Isu Berkaitan Faraq dan Cadangan Penambahbaikan bagi Menangani Kes Faraq Perkahwinan Pasangan Tak Sah Taraf di Negeri Sembilan}

Berikut adalah pandangan hasil daripada temu bual yang telah dijalankan terhadap pegawaipegawai-pegawai agama dan juga pengamal undang-undang syariah di Negeri Sembilan. Responden yang dipilih adalah terdiri daripada mereka yang pernah mengendalikan kes faraq perkahwinan disebabkan perwalian anak tak sah taraf dan faraq. Responden yang ditemu bual terdiri daripada tiga orang Kadi, dua orang Hakim Syarie dan seorang Peguam Syarie.

1. Tahap keseriusan bagi kes Faraq perkahwinan berwalikan dengan wali yang tidak layak iaitu anak tidak sah taraf di Negeri Sembilan: Terdapat beberapa pandangan mengenai tahap keseriusan faraq bagi kes perwalian anak tidak sah taraf di Negeri Sembilan. Menurut Responden 1 (Pegawai Agama, 2007), faraq perkahwinan bagi kes perwalian anak tidak sah taraf di Negeri Sembilan secara umumnya berada pada tahap yang agak membimbangkan. Namun demikian terdapat juga beberapa orang responden berpandangan sebaliknya. Namun demikian, kesemua responden bersetuju bahawa sekiranya keadaan ini tidak dibendung ia sudah pasti akan membarah di dalam masyarakat. Penerangan berterusan dari pelbagai peringkat secara tersusun perlu dibuat bagi membendung berlakunya kelahiran anak luar nikah dan mewalikannya sehingga menyebabkan perkahwinan terpaksa difaraqkan. Sekiranya tindakan segera tidak diambil akan menyebabkan perkara ini akan membarah dan sukar untuk dibendung lagi.

2. Punca Berlaku Perkahwinan berwalikan dengan Wali Yang Tidak Layak iaitu Anak Tidak Sah Taraf: Responden secara umumnya menyatakan bahawa punca utama berlakunya perkahwinan yang berwalikan dengan wali yang tidak layak disebabkan anak tak sah taraf adalah disebabkan kejahilan dan sikap tidak peduli tentang hukum hakam. Menurut responden 1 yang juga merupakan seorang pegawai agama yang berpengalaman, agama secara jelas telah menggariskan syarat-syarat seseorang wali dan pihak yang diwalikan. Bahkan di dalam kursus-kursus perkahwinan yang dilaksanakan, perkara ini telah pun diterangkan. Berdasarkan responden 2 (Pegawai agama 2017), selain dari kurang pemahaman agama, sikap mengambil mudah dengan tidak menyelidik secara terperinci tentang latar belakang dan kesilapan dalam memperoleh maklumat mengenai latar belakang calon pasangan juga adalah merupakan antara punca kes perwalian terhadap anak tidak sah taraf. Seperti juga dengan responden sebelum ini, responden 3 (Pegawai agama 2017), responden 5 (Hakim Mahkamah Syariah 2017) dan responden 6 (Hakim Mahkamah Syariah 2017) berpandangan bahawa punca utama berlakunya kes perwalian anak tidak sah taraf dengan wali ialah kejahilan dalam agama. Menurut responden 4 pula, kes perwalian anak tak sah taraf berlaku adalah disebabkan untuk menutup keaiban keluarga daripada diketahui umum. Keadaan ini berlaku adalah disebabkan kejahilan terhadap agama tanpa memikirkan kesan terhadap kesahan perkahwinan dan status zuriat yang bakal dilahirkan. Maka menjadi tanggung jawab kepada semua, terutama pejabat agama untuk menambah baik modul-modul kursus perkahwinan, memuat naik dalam teks-teks khutbah dan sebagainya mengenai bahaya anak tak sah taraf dan kaitan dengan perwalian. 
3. Keberkesanan Peruntukan Perundangan sedia ada dalam mengawal berlakunya Pembubaran Perkahwinan (Faraq) disebabkan Pasangan Yang Tidak Sah Taraf: Responden 1 berpandangan bahawa penambahan terhadap peruntukan dalam Enakmen Undang-Undang Keluarga Islam (Negeri Sembilan) 2003 perlu dibuat. Ini kerana peruntukan sedia ada tidak memperuntukkan denda atau hukuman yang boleh dikenakan ke atas wali dan pasangan tersebut. Responden 2 pula berpendapat, selain daripada peruntukan undang-undang bagi membendung kes perwalian anak tak sah taraf, pendedahan maklumat berkenaan terhadap perkara ini perlu juga dibuat. Tambah responden 2 lagi, pegawai agama (kadi) dan juru nikah perlu membuat peringatan tegas sebelum meluluskan permohonan perkahwinan dan sebelum akad nikah dilangsungkan. Responden 3 menyatakan, Enakmen Undang-Undang Keluarga Islam (Negeri Sembilan) 2003 sedia ada tidak mencukupi bagi menangani kes perwalian anak tak sah taraf. Syarat-syarat semasa permohonan perkahwinan dibuat perlu diperketat oleh pihak Jabatan Agama Islam Negeri seperti mewajibkan pengesahan nasab melalui akuan bersumpah. Menurut responden 4, 5 dan 6, apa yang perlu ditekankan ialah aspek penguatkuasaan dan meningkatkan penalti bagi pihak yang melakukan kesalahan tersebut.

4. Kaedah yang digunakan oleh Jabatan Agama Islam Negeri Sembilan untuk mengawal berlakunya kes pembubaran perkahwinan disebabkan pasangan yang tidak sah taraf: Untuk mengawal berlakunya kes pembubaran perkahwinan disebabkan pasangan yang tidak sah taraf, kesemua responden menyatakan bahawa Jabatan Agama Islam Negeri Sembilan perlu menjalankan sesi penerangan secara berterusan kepada masyarakat. Sesi penerangan boleh dibuat melalui pelbagai kaedah antaranya di dalam modul kursus pra perkahwinan. Selain itu, kempen kesedaran dalam pelbagai bentuk lain mengenai tindakan tegas berkaitan hamil luar nikah serta persetubuhan haram juga perlu dilaksanakan supaya masyarakat benar-benar memahami implikasi daripada perbuatan ini. Responden 6 berpendapat peraturan berkaitan urusan permohonan nikah perlu diperketat bagi mengawal berlakunya kes pembubaran perkahwinan disebabkan pasangan yang tidak sah taraf. Di samping itu, perkara berkaitan wali dan kepentingannya perlu diberi penekanan khusus ketika pasangan menghadiri kursus pra perkahwinan.

5. Mengawal atau mencegah berlakunya kes pembubaran perkahwinan disebabkan pasangan yang tidak sah taraf di Negeri Sembilan: Responden 2, 3 dan 4 mencadangkan agar pihak Jabatan Agama Islam Negeri Sembilan melakukan semakan dengan teliti terhadap setiap dokumen yang diserahkan ketika permohonan perkahwinan dibuat. Selain itu, Jabatan Agama Islam Negeri Sembilan perlu mempertingkatkan penguatkuasaan dan tindakan terhadap pihak-pihak yang melakukan kesalahan ini. Menurut responden 4 lagi, selain daripada memperhebat kempen jauhi zina, hukuman bagi kesalahan berkaitan perlu ditambah dan program-program pemahaman dan kesedaran kepada masyarakat perlu di perhebatkan (Hakim Mahkamah Syariah 2017). Responden 5 menekankan supaya ibu bapa dan penjaga lebih cakna dalam permasalahan ini.

6. Keperluan mewujudkan Prosedur Operasi Standard (SOP) berkaitan Faraq Perkahwinan di Negeri Sembilan: Responden 1, 2, 3 dan 4 berpendapat bahawa perlu diwujudkan Prosedur Operasi Standard (SOP) yang jelas bagi menangani kes-kes sebegini di Negeri Sembilan seperti mewujudkan dokumen akuan bersumpah semasa permohonan perkahwinan dibuat. Walau bagaimanapun, responden 5 dan 6 berpandangan bahawa kaedah sedia ada sudah 
pun memadai. Terdapat keperluan untuk memberi penerangan kepada masyarakat terutamanya dalam kursus pra perkahwinan dan semasa proses permohonan perkahwinan dibuat oleh wali.

Kesimpulannya, perkembangan semasa berkenaan kes anak tak sah taraf di kalangan umat Islam di Malaysia amatlah membimbangkan. Bagi menangani keadaan ini, semua pihak termasuk pihak kerajaan, swasta, institusi-institusi pendidikan, sekolah dan ahli masyarakat setempat mestilah turut sama memainkan peranan masing-masing. Dalam erti kata lain, perkara ini tidak boleh semata-mata diletakkan atas bahu jabatan agama sahaja. Implikasi daripada peningkatan anak-anak tak sah taraf ini akan mengundang banyak permasalahan terutama berkaitan hukum hakam. Peningkatan bilangan anak tak sah taraf akan menjurus kepada berlakunya kes perwalian terhadap anak tak sah taraf yang akhirnya menyebabkan sesuatu perkahwinan itu akan difaraqkan.

Majlis Agama Negeri-Negeri perlu memainkan peranan dengan memberi penerangan kepada masyarakat mengenai kesan perkahwinan hasil perwalian dengan wali yang tidak sah taraf dengan pihak yang diwalikan. Modul kursus pra dan pasca perkahwinan perlu memberi penekanan terhadap anak tak sah taraf dan hubungan dengan perwalian serta kesan terhadap perkahwinan. Perakuan bersumpah pengesah taraf antara pihak yang ingin berkahwin dengan wali juga perlu dibuat setiap kali permohonan perkahwinan dikemukakan bagi tujuan untuk melahirkan perasaan tanggung jawab dan secara tidak langsung dapat mengelakkan berlakunya perwalian dengan anak tak sah taraf. Oleh itu, penyelesaian secara serius perlu dijalankan secara bersama oleh jabatanjabatan agama, pemerintah dan semua pihak termasuklah mengenakan tindakan yang lebih keras terhadap pihak-pihak yang disabitkan kesalahan melakukan perwalian dengan anak tak sah taraf.

\section{References}

Al-Syirazi, Abu Ishaq Ibrahim ibn Ali ibn Yusof al-Fairuz Abadi. (1996). A-Muhazzab fi Fiqh al-Imam al-Syafie. Beirut: Dar al-Qalam.

Ali al-Khafif. (2008). Furaq al-Zawaj fi al-Mazahib al-Islamiyyah. Cairo: Dar al-Fikr al-Arabiy.

Al-Bukhari, Abu Abdullah Muhammad ibn Ismail. (1422h). Sahih al-Bukhari. T.tp: Dar Thuq alNajah.

Enakmen Undang-Undang Keluarga Islam (Negeri Sembilan) 2003.

Ibrahim Mustafa. (1989). Al-Mu'jam al-Wasit. Istanbul: Dar al-Nadwah.

Jabatan Kemajuan Islam Malaysia. (27 February 2017). Faraq. http://www.islam.my/sites/ default/files/faraq.

Mustafa al-Khin \& Mustafa al-Bugha. 1996. al-Fiqh al-Manhaji 'ala Mazhab al-Imam al-Syafie. Damascus: Dar al-Qalam.

Sophia Ahmad. (13 September 2016). Berita Harian: Anak Tak Sah Taraf Didaftar Sejak 2013: JPN. https://www.bharian.com.my/node/192319.

Responden 1: Tengku Nor Iftah Bin Tengku Jamil, Pegawai Agama Seremban. Interview, 12 July 2017.

Responden 2: Alyasak Bin Berhan, Pegawai Agama Tampin (Kadi). Interview, 17 July 2017.

Responden 3: Rozimi Bin Zamri, Pegawai Agama Seremban (Kadi). Interview, 25 July 2017.

Responden 4: Japri Bin Bahari, Pegawai Syariah. Interview, 01 August 2017.

Responden 5: Azmi Bin Aziz, Pegawai Syariah. Interview, 01 August 2017.

Responden 7: Suriany Awaludin, Peguam Syarie N9. Interview, 04 August 2017.

Al-Tirmizi, Muhammad ibn Isa ibn Surah. (1975). Sunan al-Tarmizi. Cairo: Matba'ah al-Bab alHalabi.

Uqlah, Muhammad. (1990). Nizam al-Usrah fii al-Islam. Amman: Maktabah al-Risalah al-Hadithah. 
Zaydan, Abdul Karim (2012). Al-Mufassal fi Ahkam al-Mar'ah wa al-Bait al-Muslim fi al-Syariah alIslamiyyah. Beirut: Mu'asasah al-Risalah.

Al-Zuhailiyy, Wahbah. (2007). Al-Fiqh al-Islamiyy wa Adillatuh. Damascus: Dar al-Fikr.

\section{Senarai Kes}

Abd Halim B. Md. Hashim dan Azila Bt. Ramli @ Ismail [Mahkamah Tinggi Syariah Selangor, Shah Alam. Kes Mal Bil : 10200-012-0401-2011].

Mohammed Khafidz Bin Mohamad Ishak dan Rabiah Bt Sabri [Mahkamah Tinggi Syariah Selangor, Shah Alam. Kes Mal Bil : 10200-012-0048-2011].

Munirah binti Nordin dan Abdul Rahman bin Yusof [Kes Mal Bil. 05005-042-1936-2011].

Norasiah binti Abdul Rahman dan Mohd Nasir bin Mohd Rosly [Kes Mal Bil. 05005-042-00462012].

Norsafiah binti Zulkifli dan Mohammad Sofi bin Amran [Kes Mal Bil. 05005-042-0096-2011].

Nurul Farhana binti Lokman dan Muhammad Razin bin Hassan [Kes Mal Bil. 05005-042-21432011].

Rohayu binti Idris dan Abd Karim bin Hamzah [Kes Mal Bil. 05008-042-1157-2014].

Wan Hashim bin Wan Ahmad dan Seorang Lagi lwn Zaidah binti Mohamed Saleh [Kes Mal Bil 04100-012-0519-2009].

Zakiah Binti Zahrin dan Alim bin Abd Razak [Kes Mal Bil. 05005-042-0003-2013]. 